\title{
Improving Creative Thinking Skills by Implementing Project Based Learning on Human Organ System Material
}

\author{
Riya Irianti \\ Biology Education Departmen \\ Universitas Lambung Mangkurat \\ Banjarmasin, Indonesia \\ riyairianti5011@gmail.com
}

\begin{abstract}
This study aimed to implement Project Based Learning (PjBL) model to improve creative thinking skills of students in class XI of SMK Farmasi ISFI Banjarmasin. The method used in this research was quasi-experiment with pretest-posttest control group design. The subjects were students of class XI SMK Farmasi ISFI Banjarmasin consisting of 70 students. The data were analyzed by Anacova with pretest as covariate. Then, the students' responses on project based learning model were also investigated during the implementation of the model. This research instruments were interview, documentation and tests. The results of the data analysis showed that the significant values was 0.000 from pretest, posttest and corrected model. Students' critical thinking skills were improved using Project Based Learning (PjBL) in class XI SMK FARMASI ISFI Banjarmasin.
\end{abstract}

Keywords: Creative thingking skills, Human System, Learning Project

\section{INTRODUCTION}

Regarding the implementation of the 2013 Curriculum, the Minister of Education and Culture of Indonesia has issued a new regulation on the Graduate Competency Standards for each level of primary, elementary and senior high schools as outlined in the Regulation of the Minister of Education and Culture No. 54 of 2013. The regulation states that the Graduate Competence standard is a criterion of graduate qualification that includes attitude, knowledge, and skills.

Based on the results of the preliminary interviews by the researcher on senior high school students, it was found that in general, the students perceived that Biology lesson is difficult and they tend to memorize Biology concepts.

One of the most influencing factors in the implementation of the Biology learning process in the education unit is the learning difficulties experienced by students in learning some abstract Biological materials, such as human organ systems that cannot be seen directly. This resulted in many students who are less able to understand the material. Learning difficulties also cause students' low achievement in daily tests and semester test. Therefore, in the learning process, it is necessary to have appropriate learning model to teach the abstract material.
Learning model is a plan or a pattern used as a guide in planning learning in the classroom or tutorial learning [1]. This model is a characteristic that is raised in learning as a step to implement learning in the classroom. Learning model must be in accordance with the material which is taught because each material or concept has its own characteristics. A particular concept must use a particular model as well. If suitable model is not used, learning activities become ineffective and this condition affects students' understanding. Models of teaching are actually models of learning [1]. As we help students acquire information, ideas, skillss, value, way of thinking and means of expressing themselves, we are also teaching them how to learn. This means that teacher must help students in obtaining information, ideas, skills, ways of thinking, and in expressing their own ideas. Therefore, teacher does not give the material directly but direct students to find themselves.

The use of appropriate learning models and approaches in Biology learning is expected to be a solution as well as to achieve the learning objectives effectively and efficiently. The project-based learning model is one of the learning models recommended by the 2013 curriculum development team. In the 2013 curriculum, we recognize the basic competencies derived from core competence (KI standing for Kompetensi Inti in Indonesian language) 3, which is knowledge, and basic competencies derived from core competencies (KI) 4. Project-based learning model is usually used to achieve the learning objectives derived from KI 4 in addition to achieving the goals of KI 3 .

Project-Based Learning (PjBL) is expected to accommodate KI 3 and KI 4 in Biology learning since PjBL supports constructivistic theory that rests on the idea that students build their own knowledge in the context of their own experience. The focus of the PjBL is on the key concepts and principles of a discipline, involving students in problem-solving activities and other meaningful tasks, giving students the opportunity to work autonomously, constructing their own learning, and producing products of their work. This involved all the senses, nerves, and physical aspect of students. PjBL learning has the following steps: determining fundamental questions, designing project planning, preparing schedules, monitoring students and progressing projects, testing results, and evaluating 
experiences. PjBL learning generally has guidance, planning, creating, and processing steps [2].

Learning with creative thinking skills is a process that is used when we bring new ideas. It combines previous unfinished ideas. Creativity is a product of one's creative thinking. When one implements creative thinking in a learning practice, this can make learning meaningful so memorizing concepts of Biology material will be easy to do. Based on the research background, the researcher tried to do a learning experiment by implementation of $\mathrm{PjBL}$ model to improve creative thinking skills on human organ system material.

\section{METHOD}

This research used quasi-experiment design since this study used all subjects in the intact study group who were given treatment, not using random sampling. The subjects in the study were 70 students of class XI in SMK Farmasi ISFI Banjarmasin. The independent variable in this research was Project-Based Learning model, while the dependent variable was creative thinking skills.

The collection of data in this research was conducted by using observation, interview, documentation, and tests. The data analysis used in this research is as follows: (1) To test the effect of implementation PjBL model to students' creative thinking skills, covariance analysis (Anacova) with pretest value as covariate was used by means of SPSS version 18.0; (2) To analyze the effect of implementation of PjBL model to learning outcomes, gain score was used.

\section{FINDINGS AND DISCUSSION}

The analysis results of students' creative thinking skills after the implementation of project based learning on human organ system material in class XI of SMK Pharmacy ISFI 2016/2017 are presented in Fig. 1 as follows:

Dependent Variable:perlakuan
\begin{tabular}{|l|r|r|r|r|r|} 
Source & $\begin{array}{c}\text { Type III Sum } \\
\text { of Squares }\end{array}$ & \multicolumn{1}{c|}{ df } & Mean Square & \multicolumn{1}{c|}{ F } & \multicolumn{1}{c|}{ Sig. } \\
\hline Corrected Model & $11.443^{\mathrm{a}}$ & 17 & .673 & 5.815 & .000 \\
Intercept & .011 & 1 & .011 & .092 & .763 \\
pre & 2.741 & 1 & 2.741 & 23.676 & .000 \\
gender & .374 & 1 & .374 & 3.232 & .078 \\
post & 10.950 & 15 & .730 & 6.306 & .000 \\
Error & 6.135 & 53 & .116 & & \\
Total & 188.000 & 71 & & & \\
Corrected Total & 17.577 & 70 & & & \\
\hline
\end{tabular}
a. R Squared $=651$ (Adjusted R Squared = .539)

Fig 1. The analysis results of students' creative thinking skills after the implementation of $\mathrm{PjBL}$ on human system material

The researcher used Anacova test to analyze the data Based on the results of the data processing, the obtained significance value for the posttest variable was 0.000 . Since the value is far below $0.05, \mathrm{H}_{0}$ was rejected. It can be concluded that at the level of confidence $95 \%$, there was the effect of PjBL on the students" creative thinking skills. To know the effect of different treatment to students' creative thinking skills simultaneously can be seen from number of significance in section of corrected model.

It can be seen that the significance value is 0.000 . Since the value of significance is far below 0.05 , then $\mathrm{H} 0$ was rejected. Therefore, at $95 \%$ confidence level, it can be concluded that simultaneously learning with PjBL model gave an effect on students' creative thinking skills. PjBL helps students in learning the knowledge and skills through authentic tasks. The learning, environment, content, and tasks that are relevant, realistic, authentic, and present the natural complexity of the real world are able to provide students' personal experience with powerful suggestive message.

Likewise teaching is not an activity of transferring knowledge from teacher to student, but an activity that allows students to build their own knowledge. This is in accordance with project-based learning that in fact is more emphasis on students doing and making a work in accordance with the material being studied. This is what makes students then think creatively to create a work that can be a medium of learning for materials that are difficult for them to understand.

Creativity that is applied to this research was the creativity that focused on the product. Creativity is the ability to create new combinations of social meaning [3]. From these two definitions, creativity not only creates something new but may be a combination of something that already exists

TABLE I. Mean Score of Students' Learning OUTCOME FROM PROJECT BASED LEARNING

\begin{tabular}{|c|c|c|c|c|}
\hline Class & (KKM) & $\begin{array}{c}\text { Mean of } \\
\text { Pretest }\end{array}$ & $\begin{array}{c}\text { Mean of } \\
\text { Postest }\end{array}$ & Gain \\
\hline Control & 70 & 60.94 & 80.83 & 19.89 \\
\hline Experiment & 70 & 61.14 & 90.37 & 29.23 \\
\hline
\end{tabular}

Based on the data at Table I, the mean score of learning result from the control class was 19.89 while the mean score of learning result from the experimental class was 29.23. From the results, it can be seen that the mean score of learning outcomes from the experimental class was greater than the control class, so it can be concluded that the implementation of $\mathrm{PjBL}$ more effectively improves learning outcomes than conventional learning. The implementation of $\mathrm{PjBL}$ can improve creative thinking skills and the learning outcomes.

This study was also in line with the results of ref [4] that PjBL successfully improved academic achievement, with a deep understanding on the teaching materials, and increased motivation in learning. Consistently, the research results of the U.S. PjBL was able to increase the motivation of students and provide an overview of all level [5]. Research results in America show that projectbased learning has shown satisfactory results [6].

$\mathrm{PjBL}$ is a teaching approach developed based on the principles of constructivism, problem solving, inquiryresearch, integrated studies and reflection that emphasize the aspects of theoretical studies and applications [7]. The PjBL learning model facilitates students to develop a project both individually and in groups to produce a product-such as portfolios [8] or journals [9] whose results are then presented and revised.

To support the activities of $\mathrm{PjBL}$ in the learning process can use various resources / including through observation and reflection of activities [9]. The implementation of PjBL can facilitate the level of 
participants' independence [7] and foster student achievement and performance [10].

In addition to the curriculum and competencies that have been established in schools, learning media and models should not be too difficult to use and understand to facilitate students and teachers in learning activities. In this research, the material of the human organ system must be mastered by the students, not only for the achievement of the curriculum but according to the results of dominant observations that students find it difficult to understand the material. Project-based learning in this research facilitates students in designing a project in the form of images media of the human organ system designed by the students themselves within the specified time in accordance with the concept being taught. In the end, students will understand the concept of the human organ system because it has been studied, designed in the form of drawing, and then presented from the project work they did and created. This kind of learning process will increase the students' creativity because the teacher gives students freedom in designing their work.

\section{CONCLUSION}

Based on this current research, it could be concluded as follows. The implementation of project based learning improved students' creative thinking skills. As the significance value is $0,000>0.05$ at $95 \%$ confidence level, it can be concluded that simultaneously learning with PjBL model has an effect on students' creative thinking skills. The implementation of project based learning increases students' learning outcome. It could be seen from the the mean gain of learning outcomes from the experimental class which was greater than the control class. Thus, the implementation of PjBL more effectively improves learning outcomes than conventional learning.

\section{REFERENCES}

[1] Trianto, Model Pembelajaran Terpadu, Jakarta: Bumi Aksara, 2011.

[2] Mahanal, Susriyati, dkk, Pengaruh Pembelajaran Project Based Learning (PjBL) pada Materi Ekosistem terhadap Sikap dan Hasil Belajar Siswa SMAN 2 Malang, Malang: Jurnal Universitas Negeri Malang, 2009.

[3] U. Munandar, Pengembangan Kreativitas Anak Berbakat, Jakarta: Rineka Cipta, 2004.

[4] J. W. Thomas, A Review of Research on Project-based Learning, California, US: TheAutodesk Foundation, 2000, (Online), (http://www.autodesk.com/foundation, accessed on November 13, 2013).

[5] Y. Doppelt, "Implementation and assessment of project-based learning in a flexible environment," International Journal of Technology and Design Education, 13, 2003,pp. 255-272

[6] Miswanto, "Penerapan Model Pembelajaran Berbasis Proyek pada materiprogram Linier Siswa Kelas X SMK Negeri 1 Singosari," Jurnal Penelitian dan Pemikiran Pendidikan, Tulungagung: STAIN Tulungagung, 2011.

[7] T. Suratno, A. Dharma, and Desiree, Project-based Learning, 2007, Makalah disajikan pada kegiatan Semiloka Program Adopt A Teacher, Teacher Institute Sampoerna Foundationa Jakarta, 2 Februari 2008

[8] S. Azam, M. H. Iqbal, "Use of portfolios for assessing practice teaching of prospective science teachers," Paper presented at the annual meeting of the Australian Association for Research in Education. Adelaide, November 27-30, 2006.
[9] M. Clarke, "Reflection: Journal and reflective questions -A strategy for professional learning," Paper presented at NZAARE/AARE Conference, Auckland, Nov 29-Dec 3, 2003.

[10] A. Beveridge, J. Archer, "Motivational implications of projectbased learning for the preparation of social workers," Paper presented at the annual meeting of the Australian Association for Research in Education. Adelaide, November 27-30, 2006. 